\title{
Pemberdayaan Perempuan dalam Memanfaatkan Limbah Sampah Rumah Tangga Menjadi Barang Kerajinan Bernilai Ekonomi untuk Meningkatkan Pendapatan Keluarga
}

\author{
Yulinda Ismail dan Tineke Wolok \\ Universitas Negeri Gorontalo \\ E-mail: Yulindaismail76@gmail.com \\ DOI: https://doi.org/10.21107/pangabdhi.v5i2.6114
}

Artikel Diterima : 12 Agustus 2019/ Revisi : 7 September 2019/Terbit : 19 Oktober 2019

\begin{abstract}
Abstrak
Pengabdian ini bertujuan untuk membina dan memberdayakan kelompok masyarakat perempuan dalam hal bagaimana mengelolah limbah sampah rumah tangga menjadi kerajinan yang memiliki nilai tambah sehingga dapat meningkatkan pendapatan keluarga, melalui pelatihan keterampilan mengenai pengelolahan limbah sampah rumah tangga melalui pemanfaatan teknologi-teknologi tepat guna, sehingga dapat meningkatkan pendapatan masyarakat pada umumnya. Adapun indikator capaian produk program pengabdian yang dituju adalah sebagai berikut bagaimana mengelolah limbah sampah rumah tangga dengan mengunakan teknologi yang tepat guna sehingga menghasilkan produk kerajinan yang berkualitas,serta adanya peningkatan partisipasi masyarakat dan peningkatan swadana dan swadaya masyarakat sehingga dapat menciptakan masyarakat yang mandiri secara ekonomi.
\end{abstract}

Kata kunci: pemberdayaan perempuan, sampah rumah tangga, pendapatan keluarga

\section{PENDAHULUAN}

Persoalan lingkungan telah menjadi isu global, setelah hampir semua elemen masyarakat menyadari tentang bahaya kerusakan lingkungan yang diakibatkan pencemaran lingkungan yang disebabkan menumpuknya limbah yang dihasilkan oleh manusia berupa sampah. Karena sebagian besar masyarakat masih memandang sampah sebagai barang sisa yang tidak berguna dan bukan sebagai sumber daya yang perlu dimanfaatkan. Mayarakat dalam mengelolah sampah masih bertumpuh pada pendekatan akhir yaitu sampah dikumpulkan kemudian diangkut lalu dibuang ke TPA. Padahal timbunan sampah dengan volume yang besar dilokasi tempat pemrosesan akhir, berpotensi melepas gas metan $(\mathrm{CH} 4)$ yang dapat meningkatkan emisi gas rumah kaca dan memberikan kotribusi terhadap pemanasan global.

Secara umum pada tahun 2015 dari tiga kabupaten kota yang menggunakan jasa layanan TPA di Provinsi Gorontalo yang memberikan kontribusi volume sampah terbesar melalui jembatan timbangan adalah Kota Gorontalo dengan jumlah volume sampah sebesar \pm 28 ribu ton, dengan rata-rata \pm 77 ton perhari maka \pm $78 \%$ (60 ton/hari) berasal dari kota gorontalo, selebihnya $\pm 17 \%$ Kabupaten Gorontalo dan $\pm 5 \%$ dari Kabupaten Bone Bolango. Dibanding dengan kota metopolitan, Provinsi Gorontalo memang hanya $\pm 0,003 \%$ perhari jumlah sampah yang dihasilkan, namun demikian jumlah pertumbuhan penduduk yang meningkat dan pola hidup masyarakat yang konsumtif maka sudah saatnya masyarakat setiap individu masyarakat, sejak dini harus berusaha dan berupaya menekan/mengurang jumlah sampah yang dihasilkan terutama sampah rumah tangga. Karna sampah rumah tangga termasuk yang paling banyak dihasilkan. Sehingga berdasarkan hal tersebut pemerintah Provinsi Gorontalo akan membentuk Bank Sampah di masing-masing Kabupaten yang terdapat di Provinsi Gorontalo.

Kabupaten Boalemo terdiri dari 7 kecamatan dan 82 desa. Pada tahun 2017 luas wilayah mencapai $1.521,88 \mathrm{~km}^{2}$ dan jumlah penduduk 143.689 jiwa dengan sebaran penduduk 94 jiwa $/ \mathrm{Km}^{2}$. Dan untuk Kecamatan Tilamuta yang memiliki 12 desa . Dari 12 desa tersebut salah satunya terdapat desa Ayuhulalo yang memiliki luas desa $55,53 \mathrm{Km}^{2}$. Desa Ayuhulalo merupakan desa yang memiliki penduduk terrendah 39 jiwa per $\mathrm{km}^{2}$ berdasarkan hal tersebut bisa dilihat jumlah volume sampah yang dihasilkan dapat diperkirakan kurang lebih terdapat $9 \mathrm{KK}$. Ini berarti perlu ada usaha untuk meminimalkan jumlah volume sampah yang dihasilkan oleh masyarakat. Usaha yang dilakukan diantaranya adalah harus ada usaha 
manajemen baik untuk mengelolah sampah rumah tangga. Secara mudah manajemen sampah rumah tangga adalah bagaimana cara mengurangi sebanyak mungkin sampah keluar dari rumah, seperti melakukan reuse, recycle, reduce maupu recover adalah hal yang harus ditanamkan oleh setiap anggota keluarga.

Desa Ayuhulalo memiliki jumlah penduduk lebih besar dari laki-laki sehingga diperlukan pemberdayaan perempuan dalam hal pemanfaatan limbah sampah rumah tangga untuk menopang ekonomi keluarga. Karena di Desa Ayuhulalo sebagian besar kepala rumah tangga memiliki mata pencaharian sebagai petani jagung, yang masa panennya 4 bulan, sehingga berdasarkan hal tersebut diperlukan peran perempuan dalam memberdayakan limbah sampah rumah tangga untuk di jadikan produkproduk yang memiliki kualitas dan memiliki nilai jual sehingga akan mampu menopang pendapatan keluarga.

Perempuan di Desa Ayuhulalo memiliki kebiasaan dalam mengelolah lingkungan, terutama dalam hal pemeliharaan lingkungan, ini ditunjukan kebiasaan perempuan di Desa Ayuhulalo dalam memelihara lingkungan dengan menyapu halaman dua kali sehari,membuang sampah rumah tangga di tempatnya dengan memisahkan sampah organik dan sampah unorganik. Namun sampah-sampah organik ini dan unorganik ini belum dapat dikelolah secara maksimal, sehingga sampah-sampah rumah tangga tersebut hanya dibakar. Hal ini dilakukan karena kurangnya pemahaman mereka dalam hal pengolahan limbah sampah rumah tangga tersebut.

Perempuan dalam hal ini adalah ibu-ibu rumah tangga yang merupakan bagian dari masyarakat yang menghasilkan limba atau sampah. Aktivitas rumah tangga menyumbang sampah yang cukup signifikan ke lingkungan setiap harinya, baik sampah organik maupun sampah anorganik. Penanganan sampah anorganik relatif lebih rumit dari pada sampah organik, karna sampah unorganik yang berasal dari sampah rumah tangga bermacam-macam, seperti sampah pelastik bekas kemasan suatu produk keperluan rumah tangga, tas kresek, sedotan minuman, kaleng dll. Bermacam-macam sampah anorganik tersebut selama ini kebanyakan hanya dibuang dan menumpuk menjadi sampah.

Adanya kepedulian dari perempuan dalam hal ini adalah ibu-ibu rumah tangga untuk mengurangi sampah rumah tangga tentunya akan sangat membantu mengurang timbunan sampah. Sampah organik dan anorganik yang dihasilkan dari aktivitas rumah tangga dengan melakukan keterampilan khusus dapat disulap menjadi sesuatu yang memiliki manfaat dan dapat bernilai ekonomi, sehingga dapat menambah pendapatan bagi keluarga.

Sehingga berdasarkan hal tersebut di atas maka perlu dilakukan pemberdayaan perempuan dalam hal ini adalah ibu-ibu rumah tangga di desa Ayuhulalo bekerja sama dengan mahasiswa peserta KKS pengabdian beserta lembaga mitra dalam hal ini adalah Dinas Lingkungan Hidup dan Kehutanan Kabupaten Boalemo dalam hal memberikan pelatihan maupun bimtek kepada masyarakat khususnya perempuan di Desa Ayuhulalo. Sehingga solusi sampah di Desa Ayuhulalo dapat terselesaikan, sekaligus dapat menopang pendapatan keluarga di desa tersbut.

Adapun identifikasi masalah utama terkait dengan keadaaan yang ingin diperbaiki melalui kegiatan program KKS Pengabdian adalah kurangnya pemahaman perempuan dalam hal ini ibu-ibu rumah tangga, sebagai bagian dari masyarakat di Desa Ayuhulalo kecamatan Tilamuta Kabupaten Boalemo, tentang lingkungan hidupnya menyebabkan rendahnya kesadaran untuk turut berperan serta dalam kegiatan minimalisasi limbah sampah. Pedahal perempuan dalam hal ini adalah ibu-ibu rumah tangga merupakan penyumbang limbah domestik dari aktivitas rumah tangga yang cukup banyak.

Oleh karena itu, permasalahan yang perlu diatasi adalah bagaimana memberikan pengetahuan, keterampilan dan pengalaman kepada perempuan dalam hal ini ibu-ibu rumah tangga tersebut untuk mengolah dan mengelolah limbah sampah menjadi sesuatu yang memiliki nilai ekonomi sehingga berdampak kepada pendapatan keluarga serta berdampak positif bagi lingkungan.

\section{Usulan Penyelesaian Masalah}

Berdasarkan permasalahan di atas maka perlu adanya usulan penyelesaian masalah dalam rangka memberdayakan perempuan di Desa Ayuhulalo Kecamatan Tilamuta Kabupaten Boalemo dalam hal memanfaatkan limbah sampah rumah tangga, sehingga masyarakat dalam hal ini perempuan di desa Ayuhulalo memiliki mata pencaharian tersendiri untuk menopang kebutuhan rumah tangga sehari-hari. Adapaun usulan penyelesaian maslaha diantaranya:

1. Tahapan Analisis/Identifikasi potensi 
Pada tahapan ini yang harus di identifikasi adalah sejauh mana kesadaran masyarakat dalam hal mengelolah lingkungan mereka dan sejauh mana peran masyarakat dalam melakukan pengolah sampah terutama limbah sampah rumah tangga, tentunya yang memiliki peran penting dalam hal pengolahan tersebut adalah ibu-ibu rumah tangga itu sendiri.

\section{Pendidikan dan Pelatihan}

Tahapan ini dilakukan untuk memberikan pengetahuan dan keterampilan kepada perempuan dalam hal ini adalah ibu-ibu rumah tangga dalam mengelola limbah sampah rumah tangga menjadi barang yang memiliki nilai ekonomi yang tinggi sehingga berdampak pada pendapatan rumahtangga.

\section{Pengawasan Berkelanjutan}

Dalam tahapan pengawasan berkelanjutan ini dilakukan secara kontinue dan berkelanjutan dan pada tahapan ini juga melibatkan pemerintah setempat baik pemerintah desa, kecamatan maupun pemerintah kabupaten serta lembaga mitra akan sangat menetukan kesuksesan dari program usaha pengolahan limba sampah rumah tangga ini.

Untuk mengatasi masalah yang di hadapai oleh mitra dalam program KKS Pengabdian ini adalah sebagai berikut:

\section{Teknologi}

Teknologi yang digunakan dalam pengolahan limbah sampah rumah tangga ini adalah teknologi tepat guna yaitu teknologi yang dirancang agar dapat disesuaikan dengan aspek lingkungan,kebudayaan, sosial,politik dan ekonomi masyarakat yang bersangkutan. Selain itu teknologi tepat guna haruslah menerapkan metode yang hemat sumber daya, mudah dirawat dan tidak mencemari lingkungan.

\section{Metode}

Metode yang digunakan dalam pengolahan limbah sampah rumah tangga ini sebaiknya menggunakan prinsip 3R yaitu Reduce adalah mengurangi sampah dengan mengurangi pemakaian barang atau benda yang tidak terlalu kita butuhkan.Reuse adalah berarti memanfaatkan kembali barang yang sudah tidak terpakai dan Recycle adalah mendaur ulang barang. Dan manafaat metode ini adalah mengurangi tumpukan sampah organik dan unorganik menjadi sesuatu yang bermanfaat.
Perlu ada kebijakan pemerintah untuk mengatur persoalan limbah sampah khususnya sampah rumah tangga, mengingat sampah rumah tangga inilah yang paling banyak dihasilkan,sehingga pemerintah berperan serta untuk mengeluarkan kebijakaan untuk senantiasa menciptakan lingkungan bersih dan sehat, seperti setiap Kepala Keluarga diwajibkan untuk membuat tempat sampah yaitu tempat sampah organik dan sampah unorganik dan pemerintah perlu menjadi fasilitator dalam hal membuat bank sampah.

\section{Konsep}

Untuk mengatasi persoalah persampahan maka perlu ada konsep untuk menyelesaikan hal tersebut dengan membuat konsep bank sampah. Dimana bank sampah adalah suatu tempat yang digunakan untuk mengumpulkan samapah yang sudah dipilih.Hasil dari pengumpulan sampah yang sudah dipilih akan disetorkan ketempat pembuatan kerajinan dari sampah atau ketempat pengumpulan sampah. Sehingga melalui bank sampah ini masyarakat dalam hal ini ibu-ibu rumah tangga tertarik untuk memilih dan memilah sampah rumah tangga karena akan dinalai dengan uang.

Lembaga mitra yang bertanggungjawab dalam kegiatan ini adalah Dinas Lingkungan Hidup dan Kehutanan Kabupaten Boalemo Roslina Karim, SP sebagai Kepala Dinas. Adapun kegiatan yang dilakukan oleh dinas tersebut adalah melakukan edukasi kepada masyarakat dengan membantu dalam hal memberikan pendidikan dan pelatihan mengenai bagaimana melakukan pengolahan limbah sampah rumah tangga menjadi sesuatu yang memiliki nilai guna dan nilai harga sehingga dapat meningkatkan pendapatan keluarga bagi perempuan dalam hal ini adalah ibu-ibu rumah tangga di Desa Ayuhulalo.

\section{Profil Kelompok Sasaran Dan Potensi/Permasalahan}

Kelompok sasaran dalam kegiatan KKS pengabdian ini adalah masyarakat perempuan yakni ibu-ibu rumah tangga yang tersebar di dusun-dusun Desa Ayuhulalo Kecamatan Tilamuta Kabupaten Boalemo yang memiliki permasalahan yang sama yaitu kurangnya tenaga yang terampil dan teknologi dalam melakukan pemanfaatan pengolahan limbah sampah rumah tangga.

\section{Kebijakan}


Tabel 1. Kelompok Sasaran, Potensi dan Permasalahannya

\begin{tabular}{|c|c|c|}
\hline $\begin{array}{c}\text { Kelompok } \\
\text { Sasaran }\end{array}$ & Potensi & Permasalahan \\
\hline $\begin{array}{l}\text { Masyarakat } \\
\text { perempuan } \\
\text { ibu-ibu rumah } \\
\text { tangga }\end{array}$ & $\begin{array}{l}\text { - Adanya prakarsa } \\
\text { masyarakat } \\
\text { perempuan untuk } \\
\text { mengelolah } \\
\text { sampah menjadi } \\
\text { sesuatu yang } \\
\text { memiliki nilai } \\
\text { ekonomi } \\
\\
\text { - Limbah sampah } \\
\text { rumah tangga } \\
\text { baik organik } \\
\text { maupun } \\
\text { unorganik yang } \\
\text { akan dijadikan } \\
\text { bahan baku } \\
\text { ulahan barang } \\
\text { yang memiliki } \\
\text { nilai guna } \\
\\
\text { - Adanya } \\
\text { keterbukaan } \\
\text { masyarakat } \\
\text { perempuan ibu- } \\
\text { ibu rumah tangga } \\
\text { atas kesulitan } \\
\text { yang dihadapi } \\
\text { dan terus } \\
\text { mencari solusi } \\
\text { untuk bisa } \\
\text { memenuhi } \\
\text { standar agar bisa } \\
\text { terterima oleh } \\
\text { konsumen }\end{array}$ & $\begin{array}{l}\text { - Keterbatasan } \\
\text { pengetahuan dan } \\
\text { ketrampilan dalam } \\
\text { mengolah limbah } \\
\text { sampah rumah } \\
\text { tangga menjadi } \\
\text { sesuatu yang } \\
\text { bernilai guna dan } \\
\text { bernilai ekonomi } \\
\text { - Upaya pengolahan } \\
\text { limbah sampah } \\
\text { rumah tangga } \\
\text { menjadi produk } \\
\text { yang memiliki nilai } \\
\text { ekonomis menemui } \\
\text { kendala teknis, } \\
\text { baik dari segi } \\
\text { kualitas } \\
\\
\text { Pengetahuan } \\
\text { masyarakat } \\
\text { perempuan yakni } \\
\text { ibu-ibu rumah } \\
\text { tangga terhadap } \\
\text { penggunaan } \\
\text { teknologi atas } \\
\text { produk hasil olahan } \\
\text { limbah sampah } \\
\text { rumah. }\end{array}$ \\
\hline $\begin{array}{l}\text { Tim } \\
\text { Pembentukan } \\
\text { Bank Sampah }\end{array}$ & $\begin{array}{l}\text { - Terdapatnya } \\
\text { penumpukan } \\
\text { sampah di desa } \\
\text { Ayuhulalo, } \\
\text { khususnya } \\
\text { sampah-sampah } \\
\text { rumah tangga } \\
\text { yang di hasilkan } \\
\text { oleh ibu-ibu } \\
\text { rumah tangga }\end{array}$ & $\begin{array}{c}\text { - Belum dibentuknya } \\
\text { bank sampah di } \\
\text { Desa Ayuhulalo }\end{array}$ \\
\hline
\end{tabular}

Target dan Luaran yang akan dicapai dalam pelaksanaan KKN-PPM Pengabdian ini meliputi:

\section{a. Target}

1. Peningkatan Produktivitas

Pada umumnya dalam melakukan pemanfaatan pengolah limbah sampah menjadi produk-produk yang memiliki kualitas dan nilai jual perlu dilakukan peningkatan produktivitas melalui pemanfaatan teknologi yang tepat guna. Sehingga diharapkan dengan pelaksanaan KKS Pengabdian ini akan dapat mengoptimalisasikan hasil olahan limbah sampah rumah tangga dengan cara yang lebih baik, sehingga dapat meningkatkan pendapatan masyarakat khususnya ibu-ibu rumah tangga di Desa Ayuhulalo kecamatan Tilamuta Kabupaten Boalemo.

2. Efisiensi Biaya

Pemerintah secara bertahap dan pasti harus menanamkan dan menerapkan pentingnya sistem dan manajemen pengolahan sampah yang ideal, hal ini didasarkan pada kenyataan ukuran volume sampah baik sampah organik maupun sampah anorganik yang mengalami jumlah penumpukan. Penumpukan tersebut dapat menyebabkan pencemaran lingkungan yang dapat mengakibatkan gangguan kesehatan. Dengan menerapkan sistem manajemen pengolahan sampah,manfaat yang diperoleh antara lain mengurangi timbunan sampah. Pemilihan dan pemilahan sampah menurut jenisnya, pemprosesan sampah menurut jenis dan kegunaan dan dapat merangsang dan memotivasi masyarakat untuk hidup sehat, sehingga sampah dapat dikelola secara efisien.

\section{Perbaikan Sistem}

Melalui KKS Pengabdian ini diharapakan dapat terwujudnya perbaikan sistem penanganan sampah rumah tangga di Desa Ayuhulalo Kecamatan Tilamuta Kabupaten Boalemo melalu peran pemerintah setempat maupun masyarakat dalam hal menemukan cara pengolahan limbah sampah rumah tangga yang diantaranya pemerintah memberikan himbauan kepada masyarakat untuk senantiasa memelihara lingkungan rumah dengan membuat tempat sampah di pekarangan rumah masing-masing dan melalui Ketua RT dan Ketua RW yang merupakan perpanjangan tangan pemerintah desa senantiasa membuat himbauan-himbauan mengenai bagaimana memelihara lingkungan dengan bersih dengan cara membuang sampah pada tempatnya, mengingat sampah-sampah rumah tangga di pedesaan tidak terlalu diperhatikan. Selain itu perlu adanya tempat pembuangan sampah terakhir untuk menampung sisa sampah yang tidak terpakai.

\section{Peningkatan Partisipasi Masyarakat}

Melalui kegiatan program KKS Pengabdian yang dibuat oleh mahasiswa dengan berkolaborasi dengan masyarakat di harapkan masyarakat desa Ayuhulalo Kecamatan Pulubala Kabupaten Gorontalo memiliki peran serta dalam mendukung program tersebut, sehingga program tersebut dapat terlaksana dengan baik. Dan ini 
dapat dilakukan dengan mengikuti pelatihan dan bimbingan teknik yang akan dilakukan oleh mahasiswa dan pemerintah serta tenaga ahli dalam hal bagaimana memanfaatkan pengolahan limbah sampah rumah tangga, sehingga masyarakat mendapatkan manfaat dan nilai guna dari pelatihan dan bimbingan teknik tersebut.

\section{Peningkatan Swadana dan Swadaya} Masyarakat atau Pemda

Dengan adanya peran masyarakat dalam hal ini perempuan di Desa Ayuhulalo Kecamatan Tilamuta Kabupaten Boalemo yakni ibu-ibu rumahtangga dalam hal pemanfaatan pengolahan limbah sampah rumah tangga, diharapkan dapat meningkatkan partisipasi masyarakat agar semakin banyak masyarakat tertarik untuk mengembangan pengolahan limbah sampah rumah tangga sehingga dapat meminimalisasi penumpukan sampah rumah tangga. Selain itu dengan terlibatnya masyarakat dalam hal pengolahan limbah sampah rumah tangga juga diharapkan dapat mengurangi tingkat penganguran dan dapat meningkatkan pendapatan masyarakat.

\section{b. Luaran}

Adapun luaran yang diharapkan dalam kegiatan KKS Pengabdian ini adalah :

1. Diharapkan melalui kegiatan pemberdayaan permpuan di Desa Ayuhulalo diharapkan para perempuan mampu mengelolah limbah sampah rumah tangga baik sampah organik maupun sampah anorganik menjadi barangbarang yang produktif dan memiliki nilai jual.

2. Dengan kegiatan pemberdayaan perempuan yang memanfaatkan limbah sampah rumah tangga diharapkan Desa Ayuhulalo dapat menjadi desa yang bersih dan asri dengan memanfaatkan sampah organik, sehingga sampah organik tidak hanya terbuang sia-sia.

\section{METODE}

Operasionalisasi Program KKS Pengabdian terdiri atas tiga tahapan yakni (1) tahap persiapan dan pembekalan; (2) tahap pelaksanaan dan (3) rencana keberlanjutan program.

\section{Persiapan dan Pembekalan}

Mekanisme pelaksanaan kegiatan program KKS Pengabdian meliputi tahapan berikut ini:

- Penyiapan dan survei lokasi KKS Pengabdian.

- Koordinasi dengan pemerintah desa dan kecamatan kegiatan KKS Pengabdian.

- Perekrutan mahasiswa peserta KKS
Pengabdian kerjasama dengan LPPM UNG.

- Pembekalan dan pengasuransian mahasiswa peserta KKS Pengabdian.

- Persiapan materi pelatihan dan kelengkapan administrasi.

- Penyiapan sarana bantuan alat pengolahan dan perlengkapan.

Materi persiapan dan pembekalan mahasiswa mencakup teori dan praktek beberapa aspek dibawah ini :

1. Fungsi Mahasiswa dalam KKS Pengabdian.

2. Kewirausahaan dan membangun pola pikir masyarakat melalui community development.

3. Memberikan materi pelatihan kepada masyarakat perempuan yakni ibu-ibu rumah tangga yang sebagai sasaran dari program KKS Pengabdian dalam hal bagaimana mengelolah dan memanfaatkan limbah sampah rumah tangga.

4. Memberikan pelatihan bagaimana Pengolahan keuangan dan pencatatan termasuk perhitungan biaya usaha

\section{Pelaksanaan}

Terdapat enam dusun yang akan menjadi kelompok sasaran untuk pengolahan limbah sampah rumah tangga yang akan menjadi mitra pendamping mahasiswa peserta KKS Pengabdian yang ada di Desa Ayuhulalo Kecamatan Tilamuta Kabupaten Boalemo, dengan memberdayakan perempuan yakni ibu-ibu rumah tangga dalam melaksanakan kampanye gerakan reduksi dan daur ulang sampah, memfasilitasi forum lingkungan dan organisasi perempuan sebagai mitra dan menelusuri pedoman investasi dan kemitraan untuk meningkatkan minat swasta untuk bekerja sama dengan organisasi perempuan yang akan dibentuk dalam rangka memberdayakan mereka bersama dengan mahasiswa peserta KKS Pengabdian.

Metode yang digunakan dalam melakukan pemberdayaan kelompok perempuan yakni ibuibu rumah tangga proses pemberdayaan dilakukan pada saat perencanaa mulai dari survey lokasi sampai dengan merencanakan sistem pengelolaan, kebutuhan peralatan.. Pembelajaran disertai praktek akan dilakukan oleh mahasiswa bersama-sama dengan kelompok masyarakat perempuan yakni ibu-ibu rumah tangga. Adapun langkah operasional untuk 
mengatasi permasalahan adalah :

$\checkmark$ Pewadahan terdiri dari pewadahan individual dan pewadahan komunal.

$\checkmark$ Jumlah wadah sampah minimal 2 buah untuk pemilihan jenis sampah, sampah organik dan sampah unorganik.

$\checkmark$ Pengumpulan langsung kerumah-rumah masyarakat.

$\checkmark$ Pembentukan bank sampah.

$\checkmark$ Pemanfaatan dan daur ulang sampai di sumber TPS.

$\checkmark$ Pembimbingan metode pencatatan dan perhitungan pembiayaan usaha.

Pekerjaan yang akan dilakukan oleh mahasiswa dihitung dengan menggunakan Jam Kerja Efektif Mahasiswa (JKEM) dalam sebulan. Uraian tabel dalam bentuk program dan jumlah mahasiswa pelaksananya adalah:

Tabel 2. Volume Pekerjaan

\begin{tabular}{|c|c|c|c|c|}
\hline No & $\begin{array}{c}\text { Nama } \\
\text { Pekerjaan }\end{array}$ & Program & $\begin{array}{l}\text { Volume } \\
\text { (JKEM) }\end{array}$ & Keterangan \\
\hline 1. & $\begin{array}{l}\text { Proses } \\
\text { Persiapan }\end{array}$ & $\begin{array}{l}\text { - Tahap } \\
\text { Identifikas } \\
\text { - Tahapan } \\
\text { pembagian } \\
\text { Tugas } \\
\text { - Tahapan } \\
\text { Sosialisasi }\end{array}$ & 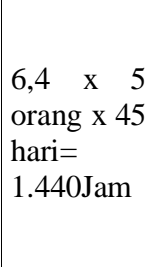 & $\begin{array}{l}5 \text { orang } \\
\text { mahasiswa }\end{array}$ \\
\hline 2. & $\begin{array}{l}\text { Proses } \\
\text { Penyortir- } \\
\text { an limbah } \\
\text { sampah } \\
\text { rumah } \\
\text { tangga } \\
\text { /pemilah- } \\
\text { an sampah }\end{array}$ & $\begin{array}{l}\text { - Proses } \\
\text { Pemilihan } \\
\text { dan } \\
\text { pemisahaan } \\
\text { limbah } \\
\text { sampah } \\
\text { rumah } \\
\text { tangga }\end{array}$ & $\begin{array}{lrr}6,4 & x & 5 \\
\text { orang } & x & 45 \\
\text { hari } & = \\
1.440 & \text { Jam }\end{array}$ & $\begin{array}{l}5 \text { orang } \\
\text { mahasiswa }\end{array}$ \\
\hline 3. & $\begin{array}{l}\text { Proses } \\
\text { pengolah- } \\
\text { an limbah } \\
\text { sampah } \\
\text { rumah } \\
\text { tangga }\end{array}$ & $\begin{array}{l}\text { - Praktek } \\
\text { pembuatan } \\
\text { pupuk } \\
\text { sampah } \\
\text { organik } \\
\text { - Praktek } \\
\text { pembuatan } \\
\text { dan } \\
\text { pengolahan } \\
\text { sampah } \\
\text { anorganik } \\
\text { - Praktek } \\
\text { desain } \\
\text { untuk } \\
\text { pembuatan } \\
\text { sampah } \\
\text { anorganik } \\
\text { - Pengurusan } \\
\text { izin untuk } \\
\text { pendirian } \\
\text { bank } \\
\text { sampah }\end{array}$ & $\begin{array}{lrr}6,4 & x & 5 \\
\text { orang } & x & 45 \\
\text { hari } & = \\
1.440 & \mathrm{Jam}\end{array}$ & $\begin{array}{c}5 \text { orang } \\
\text { mahasiswa }\end{array}$ \\
\hline
\end{tabular}

\begin{tabular}{|c|c|c|c|c|}
\hline No & $\begin{array}{c}\text { Nama } \\
\text { Pekerjaan }\end{array}$ & Program & $\begin{array}{l}\text { Volume } \\
\text { (JKEM) }\end{array}$ & Keterangan \\
\hline & & $\begin{array}{l}\text { - SK Tim } \\
\text { Pembentu- } \\
\text { an } \\
\text { Pengelolah- } \\
\text { an Bank } \\
\text { Sampah }\end{array}$ & & \\
\hline 4. & $\begin{array}{l}\text { Akuntansi } \\
\text { dan } \\
\text { keuangan }\end{array}$ & $\begin{array}{l}\text { - Praktek } \\
\text { pencatatan } \\
\text { dan } \\
\text { perhitungan } \\
\text { pembiayaan } \\
\text { usaha }\end{array}$ & $\begin{array}{l}6,4 \text { × } 2 \\
\text { orang x } 45 \\
\text { hari = 576 } \\
\text { Jam }\end{array}$ & $\begin{array}{c}2 \text { orang } \\
\text { mahasiswa }\end{array}$ \\
\hline 5. & $\begin{array}{l}\text { Praktek } \\
\text { pengadaan } \\
\text { unit } \\
\text { pewadahan } \\
\text { sampah } \\
\text { organik } \\
\text { dan } \\
\text { aunorganik }\end{array}$ & $\begin{array}{l}\text { - Pembuatan } \\
\text { pewadahan } \\
\text { sampah } \\
\text { organik dan } \\
\text { anorganik } \\
\text { - Penyerahan } \\
\text { bantuan } \\
\text { pewadahan }\end{array}$ & $\begin{array}{l}6,4 \times 10 \\
\text { orang x } 45 \\
\text { hari = } \\
2.880 \mathrm{Jam}\end{array}$ & $\begin{array}{c}10 \text { orang } \\
\text { mahasiswa }\end{array}$ \\
\hline 6. & $\begin{array}{l}\text { Praktek } \\
\text { pemasaran } \\
\text { olahan dari } \\
\text { limbah } \\
\text { sampah } \\
\text { rumah } \\
\text { tangga }\end{array}$ & Pemasaran & $\begin{array}{l}6,4 \times 3 \\
\text { orang x } 45 \\
\text { hari }=864 \\
\text { jam }\end{array}$ & $\begin{array}{c}3 \text { orang } \\
\text { mahasiswa }\end{array}$ \\
\hline \multicolumn{3}{|c|}{ Total Volume Kegiatan } & $8.640 \mathrm{Jam}$ & 30 orang \\
\hline
\end{tabular}

\section{Rencana Keberlanjutan Program}

Keberlanjutan program akan ditentukan oleh pola kinerja mahasiswa dalam pelaksanaan kegiatan KKS Pengabdian. Penempatan mahasiswa pada semua program kegiatan adalah dalam rangka memetakan potensi dan masalah yang mungkin muncul serta solusi dan alternatifnya.Bantuan pewadahan yang diberikan akan kiranya memudahkan masyarakat untuk memisahkan limbah sampah rumah tangga, sehingga memudahkan dalam hal pemilihan sampah pada saat proses pengolahan, serta akan ada pembuatan bank sampah yang kiranya memberikan solusi bagi masyarakat agar memiliki motivasi untuk mengumpulkan sampah mereka, yang tentunya memiliki harga, sehingga tidak ada lagi sampah yang terbuang. Keberadaan bantuan ini akan meningkatkan kinerja dalam pengolahan yang dilakukan oleh kelompok sasaran. Proses pemasaran akan dilakukan oleh mahasiswa dengan melibatkan masyarakat desa di Ayuhulalo. Sehingga setelah program selesai akan diharapkan masyarakat di 
Desa Ayuhulalo akan lebih menyadari akan kebersihan lingkungan melalui pengelolaan limbah sampah rumah tangga yang memiliki nilai ekonomi sehingga berdampak pada pendapatan keluarga. Diharapkan bahwa melalui kegiatan akan tercipta kegiatan yang sama di desa-desa lain yang berdekatan dengan desa Ayuhulalo tersebut. Rencana keberlanjutan juga diusulkan melalui kegiatan yang serupa pada wilayah lain yang mempunyai potensi yang mirip dengan kelompok sasaran sebelumnya.

\section{HASIL PEMBAHASAN \\ Profil Desa Ayuhulalo}

Desa Ayuhulalo merupakan desa di wilayah Kabupaten Boalemo dengan topografi dataran rendah yang pertama kali banjir apabila meluapnya sungai Dilehito disebelah utara dan tinggihnya curah hujan dilereng pegunungan. Sementara di wilayah selatan merupakan wilayah yang langsung berbatasan dengan Desa Hungayonaa.

Desa Ayuhulalo merupakan bagian dari Daerah Aliran Sungai (DAS) Dilehito dan lahan perkebunan. Melihat kondisi geografis tersebut, maka potensi ekonomi yang berkembang di Desa Ayuhulalo adalah pertanian dan perkebunan. Selain potensi alam, di Desa Ayuhulalo menyimpan potensi yang cukup besar, yakni keragaman budaya masyarakat Desa Ayuhulalo masih dipertahankan hingga saat ini. Perayaan upacara adat dalam pesta perkawinan berupa taritarian dan rebana masih dipertahankan setiap pengadaan pesta pernikahan di Desa Ayuhulalo juga yang terjadi Perayaan maulid nabi yang merupakan pengejawantahan rasa syukur kepada Tuhan YME selalu diselenggarakan tiap tahunnya.

Melimpahnya potensi alam selalu diimbangi dengan potensi ancaman bencana, begitu juga yang terjadi di Desa Ayuhulalo. Hampir setiap tahunnya Desa Ayuhulalo terjadi banjir. Banjir terbesar pada tahun 2004 dan 2017 merupakan bukti bahwa ancaman itu dapat terjadi setiap saat. Ancaman banjir tersebut dikarenakan banyaknya sampah-sampah yang menyumbuat jalannya air, hal ini dikarenakan kurangnya kesadaran masyarakat dalam hal membuang sampah, karena sebagian besar masyarakat di desa Ayuhulalo masih membuang sampah mereka di tepian sungai sehingga menghambat jalannya air dan bisa menyebabkan banjir.. Adapun administrasi Wilayah sebagai berikut:

\section{1) Administrasi Wilayah}

Desa Ayuhulalo memiliki luas $\pm 38.097 \mathrm{Ha}$ dengan batas administrasi sebelah utara adalah Desa Piloliyanga, sebelah timur adalah Desa Limbato sebelah barat adalah Kecamatan Sumalata, dan sebelah selatan adalah desa Hungayonaa. Jarak tempuh Desa Ayuhulalo dari Kecamatan adalah $4 \mathrm{Km}$ dengan waktu tempuh \pm 10 menit, dari Kabupaten adalah $\pm 2 \mathrm{~km}$ dengan waktu tempuh \pm 8 menit, dari Ibu kota Provinsi adalah $85 \mathrm{Km}$, dari Ibu kota Negara adalah 2893 $\mathrm{km}$. Desa Ayuhulalo memiliki 3 Dusun yang terdiri dari:
a) Dusun Piloliyanga
b) Dusun Iloheluma
c) Dusun Bulotu

\section{2) Kondisi Geografis Wilayah}

Ketinggain rata-rata wilayah Desa Ayuhulalo berada pada kisaran 20 meter, dengan topografi perbukitan. Desa Ayuhulalo memiliki tanah yang cukup subur dengan tekstur halus dan kecokelatcokelatan.

\section{3). Penggunaan Lahan (Landuse)}

Penggunaan lahan (landuse) di Desa Ayuhulalo meliputi:
a) Ladang
b) Permukiman
c) Perkantoran
d) Perkebunan
e) Lainnya

Sementara itu komoditi pertanian di Desa Ayuhulalo yang menjadi andalan masyarakat ialah Jagung, Cingkeh, kacang tanah, Cabe Rawit, 22 Sedangkan aneka buah-buahan yang dibudidayakan ialah Pisang, Kelapa sawit, Langsat, Rambutan, Jeruk dan Mangga. Adapaun komoditi untuk peternakan banyak dijumpai peternakan ayam, dan sapi.

\section{4) Kependudukan}

Berikut ini adalah profil kependudukan Desa Ayuhulalo
a) Penduduk Total : 2211 Jiwa
b) Laki-laki : 1120 Jiwa
c) Perempuan : 1091 jiwa
d) Jumlah Kepala Keluarga : $580 \mathrm{KK}$

Penduduk menurut usia:
a) $0-5$
Tahun
: 175 jiwa
b) $6-13$
Tahun
: 204 jiwa
c) 14-18 Tahun
: 168 jiwa
d) 19-25 Tahun
: 261 jiwa
e) 26- 45 Tahun
: 1341 Jiwa
f) 46- 57 Tahun
: 362 jiwa 

g) > 58 Tahun
: 252 Jiwa

Keadaan sosial menurut agama:
a) Islam
: 2211 Jiwa
b) Hindhu
c) Kristen
d) Budha
e) Katholik

$:-$
$:-$
$:-$
$:-$

Keadaan penduduk menurut pendidikan
a) Belum sekolah
: 116 jiwa
b) Tidak tamat sekolah
: 259 jiwa
c) Tamat SD/MI
: 291 jiwa
d) Tamat SLTP
: 110 jiwa
e) Tamat SLTA
: 214 jiwa
f) Tamat Perguruan Tinggi
: 57 jiwa
g) Tidak sekolah
:-

Penduduk menurut mata pencaharian
a) Petani
: 243 Orang
b) Nelayan
: 7 Orang
c) Pegawai negeri
: 54 Orang
d) Honorer
: 48 orang
e) Guru
: 20 Orang
f) Pensiunan
: 3 orang
g) Tukang mesel
: 10 Orang
h) Tukang kayu
: 19 Orang
i) Jasa
: 50 Orang
j) Wiraswasta
: 99 Orang
k) Karyawan
1) Pedagang
: 1 orang
: 15 Orang

\section{Deskripsi Hasil Kegiatan \\ Sosialisasi program KKS Pengabdian}

KKS Pengabdian adalah sebuah kegiatan yang sifatnya pengabdian kepada masyarakat, sehingga mahasiswa sebagai peserta pengabdian tersebut harus mampu melaksanakan kegiatankegiatan yang sifatnya melakukan pemberdayaan kepada masyarakat dengan tujuan menciptakan suatu kegiatan-kegiatan yang mampu memandirikan masyarakat dengan upaya menciptakan iklim yang memungkinkan masyarakat untuk berkembang serta memperkuat potensi atau daya yang dimiliki oleh masyarakat tersebut. Sehingga keterlibatan mahasiswa dengan kegiatan-kegiatan tersebut harus mampu menyusun rencana-rencana kegiatan secara professional sesuai dengan kondisi dan karakter desa yang mereka tempati, sehingga mahasiswa mampu melakukan penyesuaian secara baik.

Berdasarkan hal tersebut mahasiswa harus mampu mensosialisasikan program kegiatan mereka kepada masyarakatnya yang tentunya melalui keterlibatan kepala desa dan pemerintah desa yang ada di Desa Ayuhulalo sehingga program itu mampu dilaksanakan. Keterlibatan ketiga komponen ini sangat penting dilakukan sehingga tidak terjadi kesalahan dalam menyampaikan program kerja. Adapun Program yang disosialisasikan kepada masyarakat yaitu terdiri dari dua program yaitu program inti dan program tambahan. Program inti itu sendiri terdiri dari :

$\checkmark$ Terbentuknya relawan bank sampah (Dokumen SK Kepala desa/lurah).

$\checkmark$ Melakukan pemilahan sampah organik dan sampah anorganik serta metal.

$\checkmark$ Pembuatan bak sampah.

$\checkmark$ Kerja sama dengan pengepul/pembeli sampah(BPBD/DLH).

$\checkmark$ Sosialisasi dan pelatihan pemanfaat sampah

Adapun kegiatan tambahan dapat dipilih salah satu:

1. Ekonomi kreatif

2. Gerakan pelestarian lingkungan hidup

Kegiatan inti wajib dilaksanakan dengan tujuan mampu merubah pola pikir masyarakat terutama bagaimana memanfaatkan bank sampah dan membentuk relawan bank sampah yang nantinya membantu masyarakat dalam hal mengelolah sampah secara baik sehingga sampah tersebut tidak hanya mendatangkan bahaya melainkan mampu memberikan manfaat berupa peningkatan pendapatan keluarga di Desa Ayuhulalo.
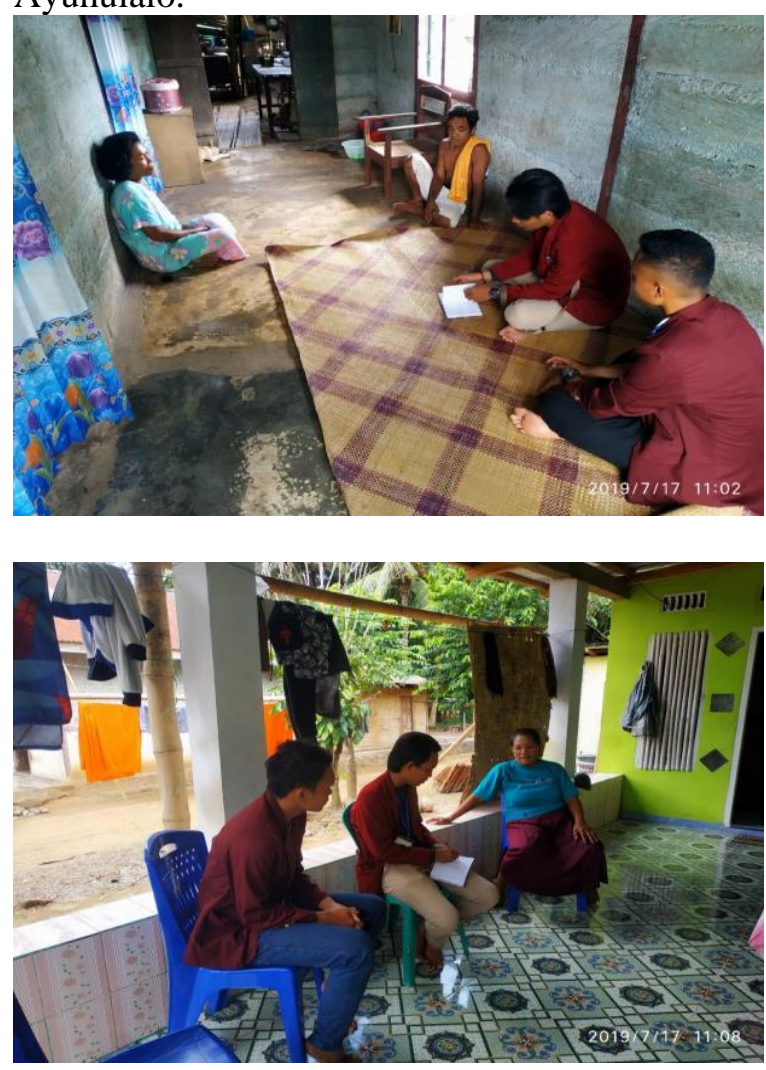

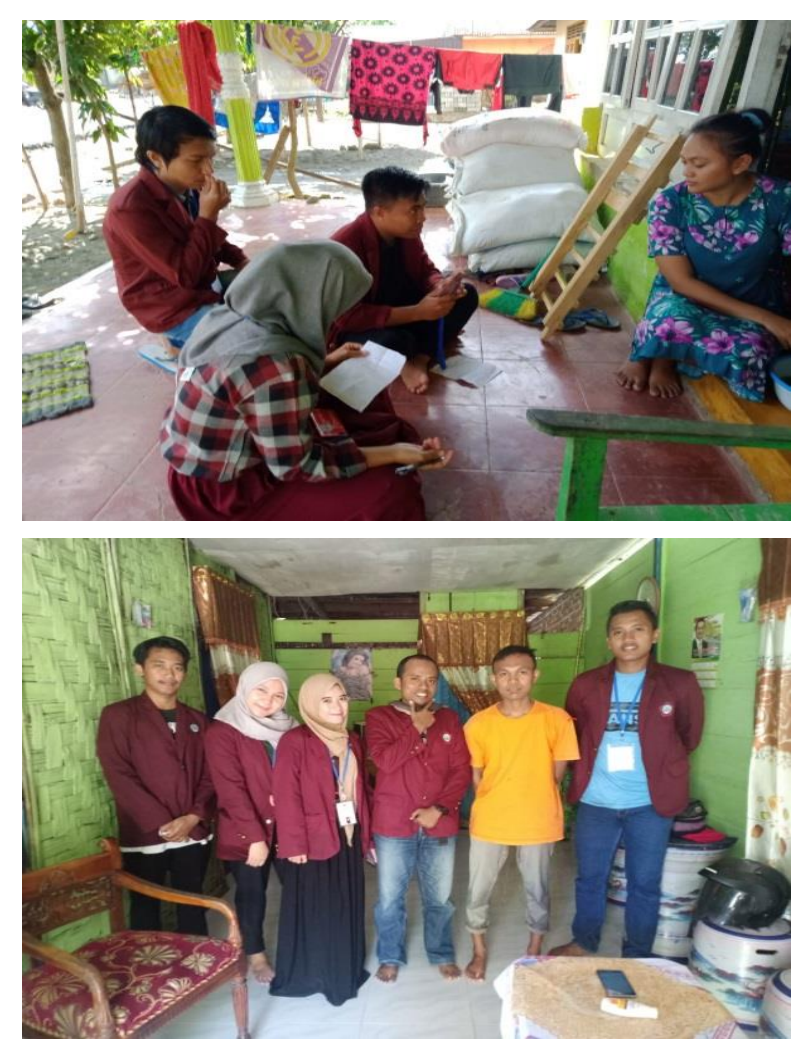

Gambar 1. Sosialisasi Program kepada Warga Desa

\section{Kegiatan Pembuatan Bak Samapah}

Dalam kegiatan pembuatan bak sampah tersebut mahasiswa beserta masyarakat bekerja sama dengan membuat bak sampah. Adapun pembuatan bak sampah itu sendiri dengan memanfaatkan limbah sampah pelastik botol yang terdapat di sekitaran wilayah Desa Ayuhulalo. Bak sampah ini nantinya ditempatkan dititik-titik tertentu yang mudah dijangkau masyarakat untuk membung sampah-sampah mereka. Bak sampah ini nantinya diharapkan mampu memberikan manfaat bagi masyarakat dan menumbuhkan kesadaran masyarakat dalam rangka membuang sampah, yang sebelumnya masyarakat di Desa Ayuhulalo membuang sampah mereka dibantaran sungai, sehingga dengan adanya bak sampah tersebut mampu meminimalisir sampah yang ada di lingkungan mereka.

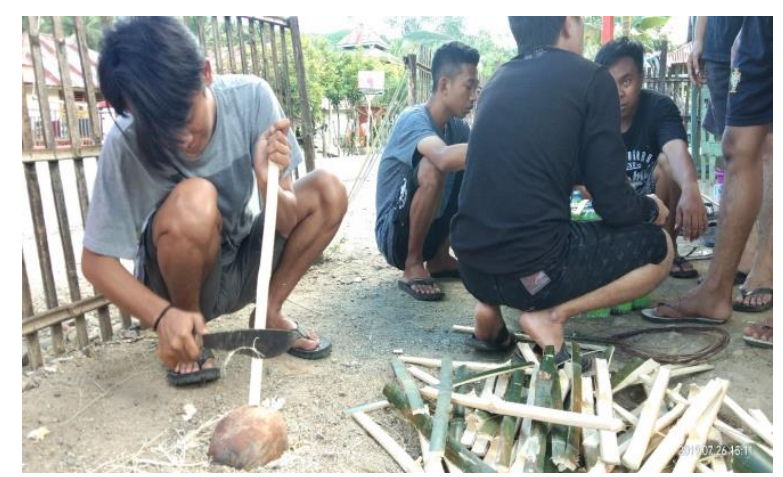

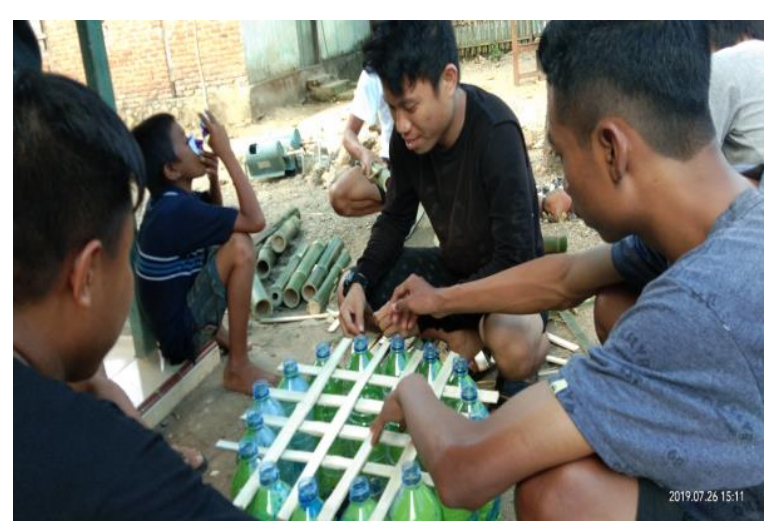
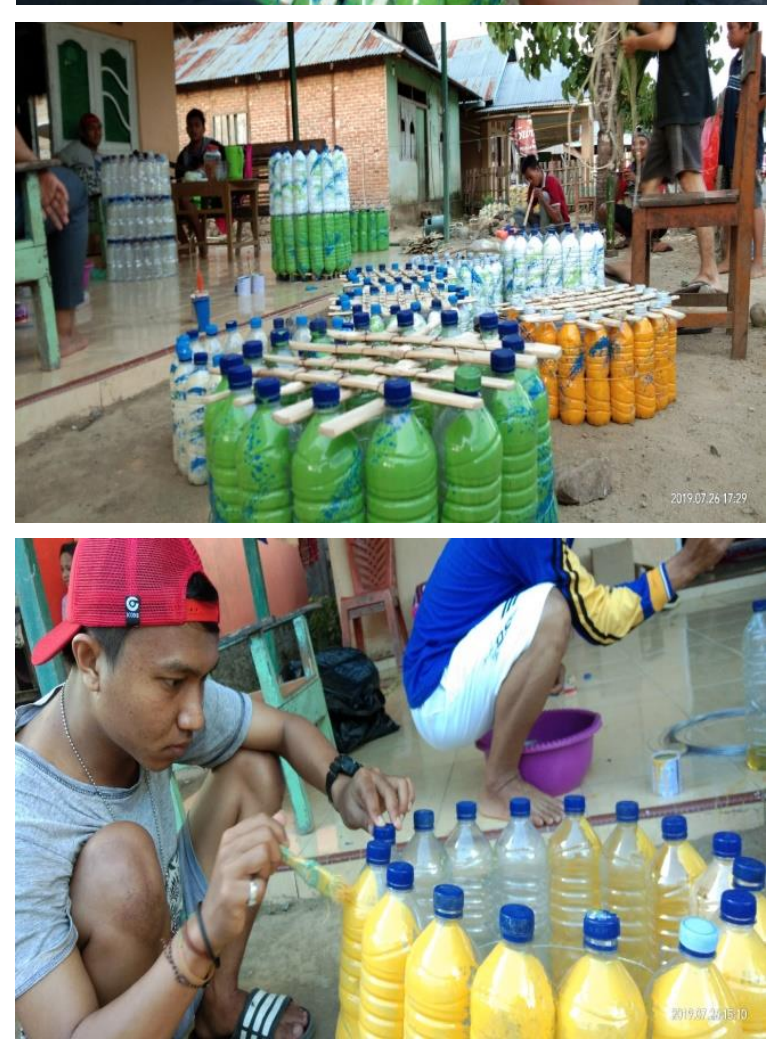

Gambar 2. Proses Pembuatan Bak Sampah

\section{Pembentukan Relawan Bank Sampah}

Dalam pembentukan relawan bank sampah ini merupakan salah satu program yang dicanangkan dalam kegiatan KKS Pengabdian ini, mengingat dengan di bentuknya relawan bank sampah ini, nantinya masyarakat di Desa Ayuhulalo nantinya dapat terbantukan dalam hal menyelesaikan persoalan sampah di desa mereka. Relawan Bank Sampah ini tugasnya memberikan pemahaman kepada masyarakat agar kiranya lebih bijak memahami persoalan sampah yang ada disekitar pemukiman mereka, selain itu relawan bank sampah juga nantinya dengan suka rela kerumahrumah penduduk untuk mengumpulkan sampah dan setelah dikumpulkan dipilih mana sampah organik dan sampah unorganik, dan kedua jenis sampah ini masing-masing memiliki manfaat. 
Untuk sampah organik bisa dijadikan pupuk yang akan dimanfaatkan pada tanaman-tanaman yang ada di pekarangan rumah mereka dengan cara diolah secara sederhana. Sedangkan untuk sampah anorganik dapat diolah menjadi berbagai jenis barang yang memiliki nilai jual, disamping itu juga sampah unorganik tanpa diolahpun dapat meningkatkan pendapatan ibu-ibu yang ada di Desa Ayuhulalo Kecamatan Tilamuta Kabupaten Boalemo.

\section{Sosialisasi dan Pelantikan Relawan Bank Sampah}

Kegiatan sosialisasi ini dilaksanakan guna menumbuhkan kesadaran pada masyarakat tentang mengelolah sampah dan memberikan pemahaman tentang bahaya sampah bagi masyarakat, dan kegiatan ini dilakukan oleh nara sumber dari Dinas Lingkungan Hidup Kabupaten Boalemo yang merupakan bagian dari pemerintah. Kegiatan sosialisasi ini dihadiri oleh masyarakat yang menjadi relawan bank sampah, sekaligus memberikan pembekalan kepada relawan tentang tugas dan fungsi mereka nantinya dimasyarakat dan kegiatan ini sekaligus pelantikan relawan bank sampah yang akan dilantik langsung oleh Kepala Desa Ayuhulalo.

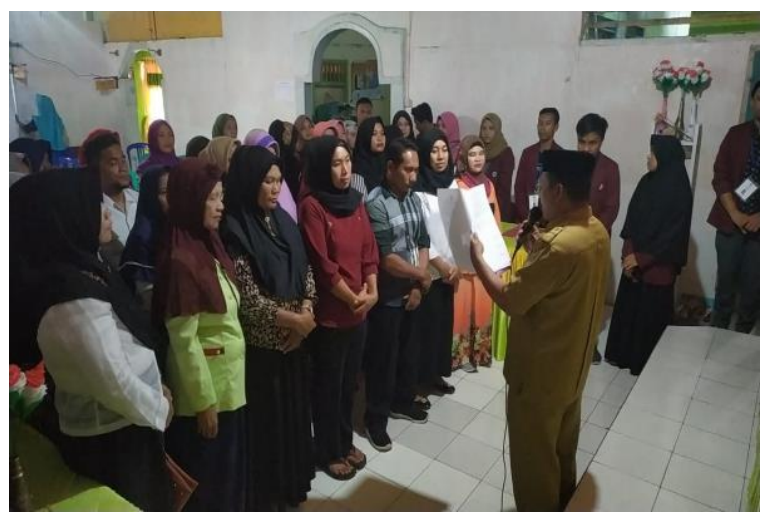

Gambar 3. Pelantikan Relawan Bank Sampah

\section{Pemberdayaan Perempuan dalam Memanfaatkan Limbah Sampah Rumah Tangga}

Kegiatan pelatihan tentang pemberdayaan perempuan dalam memanfaatkan limbah sampah rumah tangga menjadi barang-barang kerajinan yang bernilai ekonomi untuk meningkatkan pendapatan keluarga ini kiranya dilakukan untuk memberikan pengetahuan kepada masyarakat di Desa Ayuhulalo tentang bagaimana memanfaatkan limbah sampah rumah tangga menjadi barang-barang kerajinan yang bernilai ekonomi sehingga dapat meningkatkan pendapatan masyarakat khususnya masyarakat di
Desa Ayuhulalo. Karena selama ini masyarakat yang ada di desa Ayuhulalo khususnya ibu-ibu sebagai penghasil sampah terbesar yang dihasilkan dari sampah rumah tangga yang terdiri dari sampah sayuran, sampah kertas, dan sampah plastik hanya langsung dibuang ketempat pembuangan sampah, karena memang masyarakat khususnya ibu-ibu belum menyadari betul tentang bagaimana mengelolah sampah rumah tangga yang mereka hasilkan. Oleh karena itu melalui pelatihan tersebut mampu memberikan kesadaran bagi mereka untuk mengelolah sampah rumah tangga yang mereka hasilkan. Adapun materi pelatihan yang diberikan oleh nara sumber terdiri dari sebagai berikut :

$\checkmark$ Bagaimana membuat pupuk organik sederhana.

$\checkmark$ Bagaimana membuat produk-produk kerajinan dari sisa limbah-sampah rumah tangga berupa botol, dos, plastik dan bagaimana memanfaatkan limbah sampah kain lainnya.

$\checkmark$ Praktek langsung yang didampingi oleh nara sumber bagaimana membuat produk-produk sisa limbah sampah tersebut

Diharapkan melalui kegiatan pelatihan tersebut masyarakat dalam hal ini ibu-ibu rumah tangga yang didampingi oleh relawan-relawan bank sampah yang sudah dibentuk mampu memanfaatkan limbah-limbah sampah rumah tangga mereka yakni sampah organik dan sampah anorganik menjadi sesuatu yang memiliki nilai jual dan dapat meningkatkan pendapatan keluarga sehingga dapat mensejaterakan keluarga khususnya di Desa Ayuhulalo Kecamatan Tilamuta Kabupaten Boalemo.

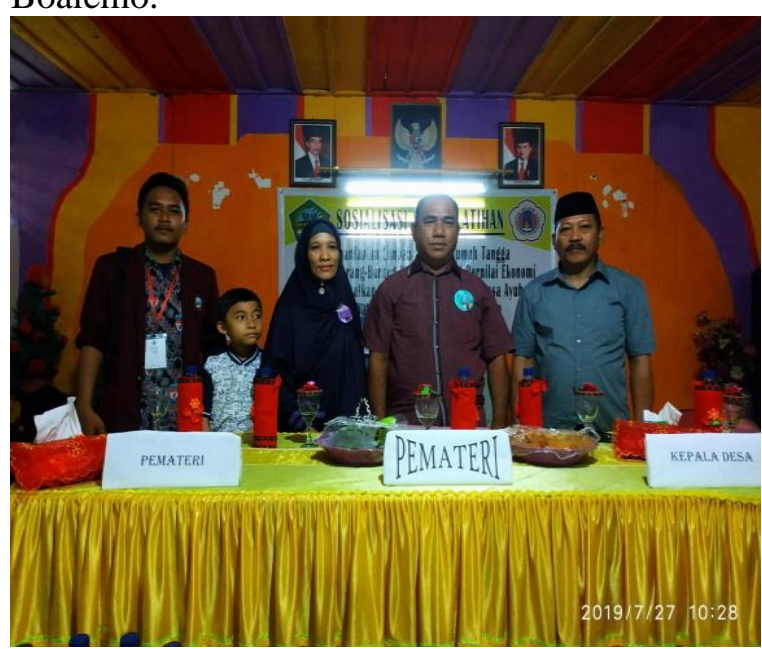

Gambar 4. Pemateri Pelatihan 

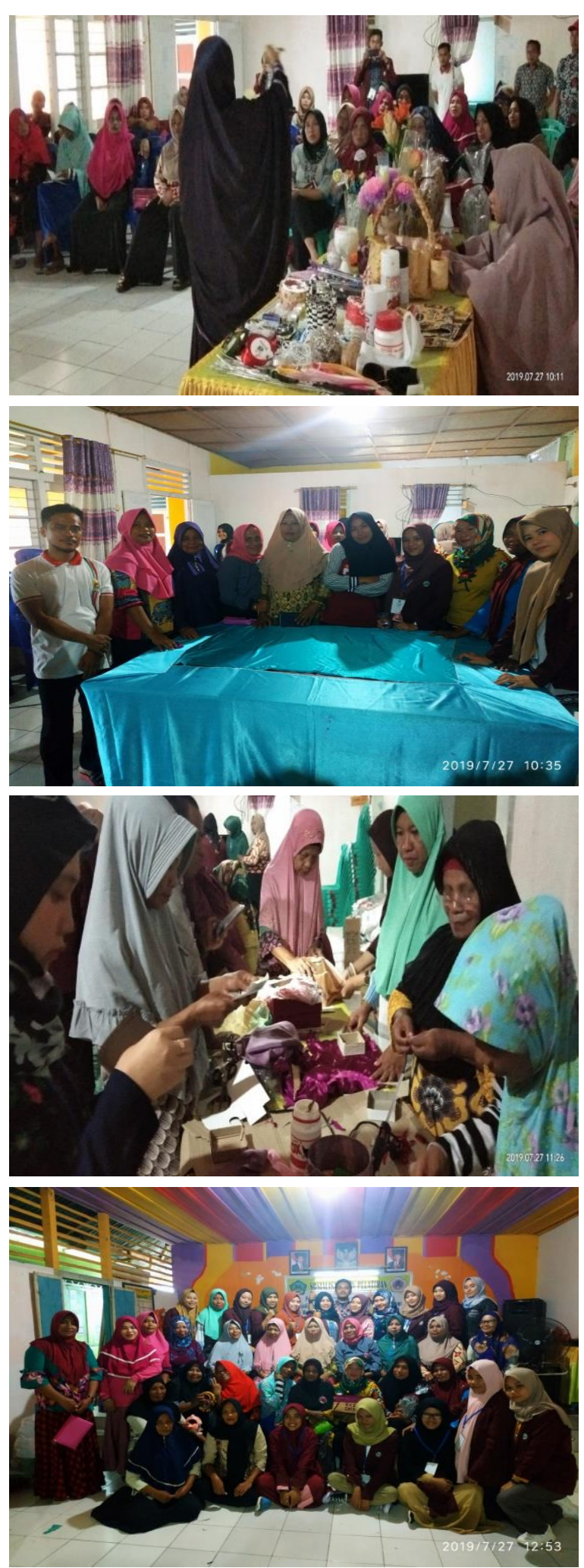

Gambar 5. Pelaksanaan Pelatihan Pemberdayaan Perempuan

\section{Inisiasi Program Go-Green}

Kegiatan Go Green ini adalah merupakan bagian dari kegiatan inti yang dilakukan mahasiswa, melalui kegiatan go green ini diharapkan masyarakat dalam hal ini ibu-ibu mampu memanfaatkan pekarangan rumah mereka dengan menanam tanaman kebutuhan sehari-hari seperti sayur mayur dan obat-obatan yang organik, sehingga dapat mengurangi belanja keluarga akan kebutuhan makanan seperti sayuran, karena sayuran sudah dihasilkan sendiri melalui pekarangan mereka sendiri, sekaligus dapat dijual sehingga mendatangkan pendapatan keluarga. Disamping itu pembuatan go green ini diharapkan nantinya masyarakat mampu mengkonsumsi sayur-sayuran yang sehat karena menggunakan pupuk organic hasil olahan mereka sendiri yang sudah di dapatkan dalam pelatihan.
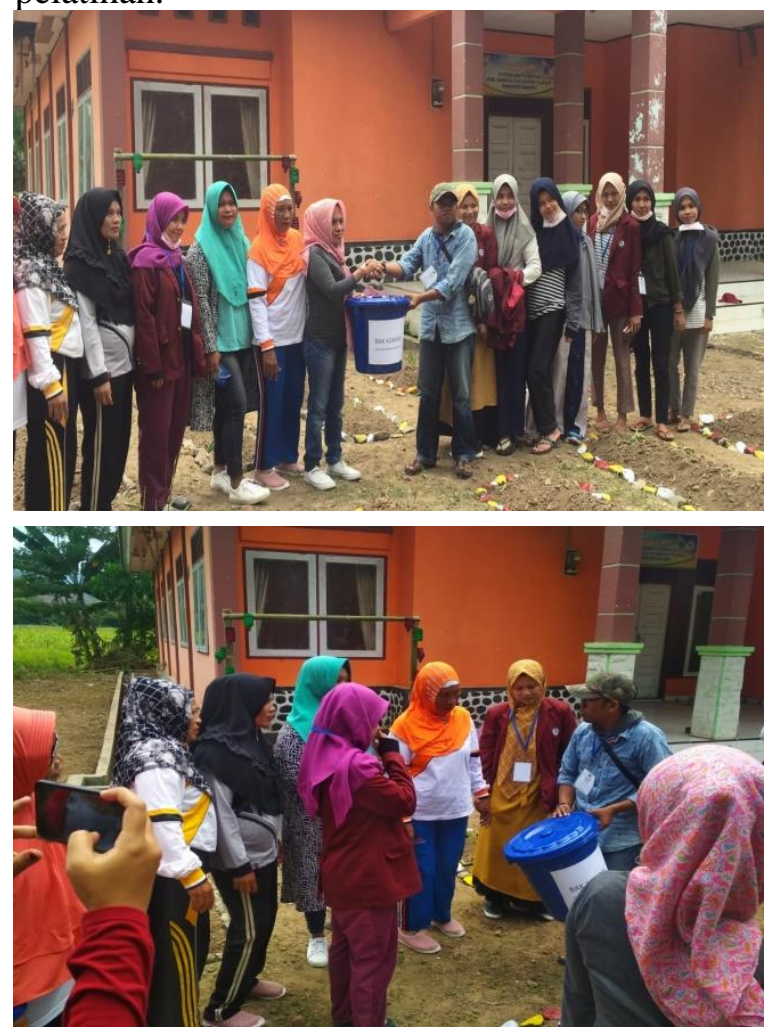

\section{Rencana Tindak Lanjut}

Kegiatan KKS Pengabdian Tematik Bank Sampah yang telah dilakukan oleh mahasiswa pada bulan Juli-Agustus tahun 2019 adalah KKS pengabdian yang dilakukan berkolaborasi dengan pemerintah dalam hal ini adalah pemerintah Kabupaten Boalemo dengan tujuan memberikan pemahaman kepada masyarakat bagaimana memberdayakan perempuan dalam memanfaatkan limbah sampah rumah tangga menjadi barang-barang kerajinan yang bernilai ekonomi guna meningkatkan pendapatan keluarga di Desa Ayuhulalo Kecamatan Tilamuta Kabupaten Boalemo. Kegiatan ini dilaksanakan melalui Pendampingan kepada masyarakat melalui pembentukan forum relawan bank 
sampah yang termuat lewat SK yang sudah di tanda tangani oleh kepala desa, membuat bak sampah, pemilahan sampah organik dan unorganik, kerjasama pengepul, sosialisasi dan pelatihan pemanfaatan sampah sehingga mampu melahirkan ekonomi kreatif dan pelestarian lingkungan.

Untuk rencana tahapan berikutnya adalah diharapkan dengan setelah dilaksanakannya KKS Pengabdian ini mampu memberikan kesadaran bagi masyarakat bagaimana memanfaatkan limbah sampah rumah tangga mereka sehingga mampu meningkatkan pendapatan bagi ibu-ibu. Dan kegiatan ini tidak hanya berlanjut sebatas adanya mahasiswa peserta KKS Pengabdian, namun terrus berlanjut menjadi kegiatan yang penting dan diprogramkan pada kegiatan Desa sekaligus menjadi perhatian bagi pemerintah desa terus meningkatkan program ini. Dan sebagai tindak lanjut kegiatan ini kepala desa Ayuhulalo dan perangkat desa lainnya memasukan kegiatan ini menjadi bagian dari program dana desa, sehingga melalui pendanaan desa masyarakat mampu membagun Bank sampah dan mampu melakukan manajemen bank sampah mereka sendiri dengan memberdayakan tim-tim relawan bank sampah yang sudah dibentuk dan dilantik oleh pemerintah desa dalam hal ini kepala desa Ayuhulalo beserta Perwakilan dari Dinas Lingkungan Hidup. Mengigat kenapa perlu dibangunnya Bank sampah di Desa Ayuhulalo karena bank sampah itu sendiri masih melekat pada Bank sampah di Dinas Lingkungan Hidup yang jarak tempunya cukup jauh. Sehingga hal tersebut menyulitkan relawan bank sampah untuk mengangkut sampah mereka.

\section{KESIMPULAN \\ Kesimpulan}

Hampir seluruh Indonesia memiliki masalah sampah tidak terkecuali masyarakat di Desa Ayuhulalo, sehingga dengan memberdayakan perempuan dalam memanfaatkan limbah sampah rumah tangga menjadi barang-barang yang memiliki nilai ekonomis di Desa Ayuhulalo sangat penting. Sehingga masyarakat di Desa Ayuhulalo mampu meminimalisir sampah yang di hasilkan oleh ibu-ibu rumah tangga melalui relawan Bank Sampah yang sudah dibentuk.

Pemerintah dalam hal ini Dinas Lingkungan hidup dan Kehutanan Kabupaten Boalemo mampu terus menerus memberikan kesadaran kepada masyarakat tentang bahaya sampah melalui kegiatan-kegiatan sosialisasi tentang bagaimana menanggulangi bahaya sampah dan dengan melaksanakan program-program yang menarik berupa pameran-pameran produk kerajinan rumah tangga yang berasal dari sampah rumah tangga. Sehingga kegiatan tersebut mampu mendorong masyarakat untuk melakukan pemilihan dan pemilahan sampah di rumah masing-masing.

\section{Saran}

1. Perlu Kerja sama antara pemerintah dalam hal ini Dinas Lingkungan Hidup dan Pemerintah Desa untuk kiranya membentuk bank sampah dibeberapa titik sehingga mampu memudahkan kerja para relawan bank sampah untuk mengumpulkan sampah sekaligus melakukan memanajemen pengelolaan sampah yang baik.

2. Melaui kegiatan KKS Pengabdian Bank Sampah ini merupakan salah satu upaya yang sangat menunjang peningkatan kemampuan masyarakat desa dalam mengelolah sampah mereka. Sehingga program ini perlu keberlanjutan dan tetap dilestarikan agar tetap berkembang melalui keterlibatan pemerintah desa yang sungguh-sungguh.

3. Dengan Pengelolaan sampah yang sistimatis dan berkelanjutan diharapkan mampu melakukan pengelolaan sampah rumah tangga dengan menggunakan teknologi yang tepat guna sehingga dapat menghasilkan produk kerajinan yang berkualitas melalui peningkatan partisipasi masyarakat, sehingga dapat menciptakan masyarakat yang mandiri secara ekonomi.

\section{DAFTAR PUSTAKA}

Badan Pusat Statistik, 2010. Hasil Sensus penduduk. Diunduh dari: http//www.bps.go.id/aboutus.php?sp=0

Hakim H. 2010. Alasan kenapa perempuan harus menjadi subjek dalam mengelola sampah. Internet : di unduh 6 Juli 2012.

Irwan Z.D. 2009. Besarnya eksploitasi perempuan dan lingkungan di Indonesia, siapa dapat mmengendalikan penyulutnya? Jakarta [ID]: Gramedia.

Masalah sampah di Indonesia. 2008. [internet]. [diunduh19 April 2012]. Diunduh dari:http://www.masalahsampah.info/2008/1 0/sampah-part-03-masalah-sampah-di.html. 